\title{
Text Reproduction of Folklore with Character Education as Enrichment of Sanggar Sastra
}

\author{
Nyayu Lulu Nadya* \\ Department of Indonesian Education and Literature, \\ Faculty of Teacher Training and Education, University of Tridinanti Palembang, \\ Palembang, Indonesia \\ nyayu_lulu_nadya@univ-tridinanti.ac.id
}

\begin{abstract}
This study aimed to determine the form of folklore containing character education and to find out how to produce folklore texts containing character education in form of synopsis. This research used descriptive method. The population and sample used were 14 students of the Indonesian Language and Literature Education Study Program of FKIP University of Tridinanti Palembang. The research data was obtained from the results of student writing in the Sanggar Sastra. In Sanggar Sastra, students were expected to be able to appreciate literary works and produce fictional writings of their own work. In addition, the scope of learning of Sanggar Sastra courses cannot be separated from material about the literary period, namely old literature and new literature. Through literary works, the author can express the problems of life from time to time, for example old literary forms in the form of folklore. There are many folklore in South Sumatra but the focus of this research used a collection of folklore published by the Balai Bahasa (Language Center) of South Sumatra in 2009. From the results of the study obtained data that, of the fourteen samples used only one student who scored very poor, one student got poor, one student achieved adequate, five students were categorized good, and six students were categorized very good.
\end{abstract}

Keywords - text reproduction, folklore, education character.

\section{INTRODUCTION}

One of the fundamental aspects in academic literacy is the activity of writing is one of the key competencies in education today (Ghanbari, Barati, \& Moinzadeh, 2012). Writing is a social activity done by people using his/her knowledge of construction and seeks to share it with others (Omar, 2019). Thus, writing can be defined as an activity in compiled and stringing words based on the information it has to be conveyed to the readers through the medium of writing (Helaluddin, 2016).

The writing process follows the same development as the reading process (Tavares, 1990). By writing, the brain will be sharpened to be sharp and critical and make knowledge increase because people who have writing skill must have reading skill too. The process of writing is a photograph or record the activity of the facts and information in the field and communicate with others (Khrabrova, 2016). There is one of reading and writing activities which can be applied, namely rewriting or reproduction of writing.

In writing reproduction activities, the process starts from reading a text, determining the main ideas, making text reproduction, and then comparing the results of the original text and text reproduction. In addition, reproductive writing has broader meaning than just writing. There are things need to be developed or discussed from reading results, whether the contents of the text can be accepted, rejected, or ignored (Beach \& James, 1990).

In learning, the process of producing text does not focus on the background. The author tends to follows the structure in order to produce text and formulate reading content. In addition, the process of producing text can also vary depending on the situational context. There are two parts of written reproduction, namely the entire text production process is focused on reproducing already known texts and the production of existing texts on scientific texts that require writers to work by integrating or adjusting to existing literature (Jakobs, 2003).

In academic life, the form of assignment "summarize" or "summarize" and "adapt" is familiar because almost every lecture meeting is faced with the task. This task is usually a companion task that usually accompanies the reading task. For the purposes of study, the skills to summaries and adaptations will greatly support the success of learning process. There are several terms in the reproductive writing that are familiar to us, namely summary, synopsis, abstracts, and paraphrases, precis. The difference in each of these terms, namely (1) summary, in the process is called summarizing to have meaning as one form/form of abbreviation of information by only presenting information or important points; (2) the summary is synonymous with precis, synopsis, abstract, and paraphrase. The four terms have similarities and closeness of meaning, but usually with different connotations and contexts; (3) synopsis is usually used for the literary environment, especially prose and drama and is used to summarize the story or play so that it still shows the steps or plot of the story; (4) paraphrasing is changing or re-expressing the language with a simpler meaning and purpose contained in the text and usually associated with poetry; (5) abstract is the essence of a piece of writing in mini form (Mulyati, 2007).

Then the old prose discussion, old prose is popularly known as folklore, because the story was born and is close to the community, even its nature is populist (Nadya \& Amalia, 2019). This collection of folklore was expected to be an alternative reading for young people in addition to books of modern literary works and was also expected to be used as material enhancing teaching material in the field of literary learning. Most people in South Sumatra only know folklore developed by word of mouth, such as the Legenda Pulau Kemaro and Si Pahit Lidah without having desire to read more. On the other hand, from the activities documented by the Language Center of the Province of South Sumatra, there are 
three titles of a collection of folktales. One of the books on folklore used in this study. Some folklore that they can read and write back in the current version, for example Sembesat Sembesit, Bujang Kurap, Raden Keling, Matripat Lanang, Asal Usul Harimau Tidak Mau Memakan Orang Rambang, and Rusa dan Burung Cencirak (Kurnianto, Nirmala, \& Rosita, 2009).

In other side, education in Indonesia is currently faced with an unfavorable situation. This condition occurs in line with the increasing number of facts about the weak character of the Indonesian nation which has been believed to be very strong and firm in holding the joints of wise and prudent life.

Character is asocial-moral competence that combines moral action, moral values, moral personality, moral emotion, moral reasoning, moral identity, and the basic characteristics (R. Ghamrawi, Ghamrawi, \& Shal, 2015). Furthermore, character education is absolutely necessary at all levels of education for their factor structure changes increasingly diverse society, such as the problem of immigrants, displacement, urbanization, to the advancement of technology and information (Khoury, 2017).

Character development education is a curriculum intended to teach students in forming a broad and responsible thinking (Tannir \& Anies, 2013). Therefore, The Ministry of National Education considers that the right effort to restore the nation's civilization is through education, because education has an important and central role in developing human potential, including mental potential. It is hoped that through education there will be transformations that can foster positive character, and change the character from bad to good. Character education is chosen to be the main road for the formation of national character in the future. It is hoped that character education will form the behavior of students who are commendable in line with universal values and noble cultural traditions (Abidin, 2016).

Based on Article 3 of Presidential Regulation No. 87/2017 about strengthening this character education is religious, honest, tolerance, discipline, hard work, creative, independent, democratic, curiosity, national spirit, love the motherland, appreciate achievement, be friendly, love peace, love to read, care for the environment social care, responsibility.

Teaching materials play an important role in the learning process. Teaching materials provide a lot of comfort and the ability of lecturers to convey messages to students in an accurate, precise, clear, and understandable way. Teaching materials that are used well, such as handouts and audio-visual materials can help the learning process be easy and last long (Saglam, 2011).

Sanggar Sastra courses are studied by fourth semester students of the FKIP Language and Literature Education Study Program at University of Tridinanti Palembang. In this course, students are asked to encourage creativity and literary expression, both written, oral, and physical. In this course the expression of students can be expressed through written expressions. The habit of writing this literary work is to practice the skills and abilities of students to express what they felt, liked, hated, or experienced. One form of writing that will be produced by students is a synopsis of South Sumatra folklore (Nadya, 2018).

From some of the above explanation, the focus of this research was to find out the folklore containing character education and produced folklore texts in the form of a synopsis. Synopsis was part of writing reproduction. Synopsis was chosen to make it easier for readers to summarize the contents of the reading by not leaving an important part of its contents.

\section{METHOD}

This research belongs to qualitative research. In qualitative research, data is collected qualitatively and can be analyzed quantitatively (Nassaji, 2015). Furthermore, a qualitative method is a scientific method emphasizing on an investigation under social and cultural phenomena, behaviors perspectives; and seeking in-depth understanding about how and why those phenomena may occur (Creswell, 2007) (Denzin \& Lincoln, 2009).

The sample in this study were 1 class consisting of 14 students. The data source used was the book of folklore in South Sumatra, which was published by the Language Center of the Province of South Sumatra in 2009. Many kinds of folklore that developed in South Sumatra. Performance test was used to collect the data, namely synopsis writing. It was intended to measure students' understanding of literary texts which were read by restating the contents of the texts concerned in their own language. The assessment rubric used was the aspect of story content, accuracy of the selection of story details, accuracy of plot development, accuracy of words and sentences, and narrative style. The range of values used was $1-5$. The description of number 1 was very poor, number 2 was poor, number 3 was adequate, number 4 was good, number 5 was very good (Nurgiantoro, 2011).

\section{RESULTS AND DISCUSSION}

\section{A. Results}

The data used were 14 titles. From the fourteen titles used, there were four titles that had only one value of character education. The rest was almost every title had a value of more than three characters education. The synopsis of the text's reproduction results assessed the student's work and the assessment depended on the student's understanding of the reading and writing results. The parts of the title that are in folklore are described as follows.

\section{1) Sang Miskin}

This story had only one-character education value, namely responsibility. From the results of making a synopsis, the evaluation criteria lied in sufficient criteria. It could be seen from the accuracy of the selection of the details of the story and the accuracy of the development of the plot was still poor, but in the appropriateness of the contents of the story, the accuracy of words and sentences, and the narrative style was said to be sufficient so that the value obtained was an average of 3.6. 


\section{2) Bujang Kurap}

This story had nine values of character education, namely religious, hard work, curiosity, love of the motherland, national spirit, care for the environment, patient and compassionate, believe in supernatural powers, and were not arrogant. In synopsis writing, all the criteria had been fulfilled so that the value obtained was 5 , which was very good.

\section{3) Sang Piatu}

This story had six values of character education. These six educational values could be developed by the authors very well. From the appropriateness of the contents of the story, the accuracy of the selection of the details of the story, the accuracy of the plot development, the accuracy of the words and sentences, and the narrative style were all worth 5 , which was very good.

\section{4) Burung Gagak and Burung Kuaw}

This story had three values of character education, namely responsibility, creative, and hard work. Only the appropriateness of the contents of the story and the accuracy of the selection of the details of the story could be developed very well. However, in the section on the development of the flow, the accuracy of words and sentences, and the narrative style of the criteria is sufficient. So, the value criteria on the synopsis of this story were very good with an average of 4.8.

\section{Kancil Bertanding Melawan Siput}

This story had four values of character education, namely hard work, independent, friendly, and honest. From all the rubric of assessment, the synopsis results made can be said to be good with a value of 4 .

\section{6) Sembesat Sembesit}

There were four values of character education that appear in this story, namely religious, hard work, curiosity, and creative. The synopsis made by the student was very good. Illustrated from each assessment criteria had a value of 5 .

\section{7) Asal Usul Harimau Tidak Mau Memakan Orang Rambang}

In this story, there was only one value of character education, namely responsibility. For the assessment of the results of making a synopsis there was enough in the category. From the results of reading the text, it appeared that there were some important missing parts which made the accuracy of the selection of details of the story had a value of 1 or very less. In addition, the accuracy of the development of the flow was made irregular so that there were stories that were not explained.

\section{8) Bujang Remalun}

In this story there were three values of character education, namely curiosity, social care, and responsibility. Overall, from the five aspects of the synopsis assessment results made by this student got a good grade or 4 .

\section{9) Asal Usul Talang Tampe Rawas}

This story had only one value of character education, which is peace. After reading from the results of the synopsis made all the assessment rubrics have a value of 2 or poor, namely in the part of the story line did not appear, incorrect story details, inaccurate story content, inadequate words and sentences, and rigid narrative style.

\section{0) Rusa and Burung Cencirak}

The value of character education that emerged as many as seven, namely tolerance, hard work, creative, democratic, friendly, social care, and responsibility. From the results of the writing everything was very good value because the author can rewrite the reading according to the flow and content of the story from the original text.

\section{1) Raden Alit}

There were three values of character education in this story, namely independence, responsibility, and social care. From the rubric of scoring all elements of the rating get a value of 4 or good because the writer understood the things that need to be the main idea and could be told properly in accordance with the storyline in the original text.

\section{2) Putri Berambut Putih}

This story had only one value of character education, namely responsibility. But from the results of the synopsis made, all of them got a value of 3 or enough. Even though the stories in the original text were very interesting to be rewritten, there were some parts that did not appear and the narrative style was still stiff.

\section{3) Matripat Lanang}

This story had two values of character education, namely hard work and responsibility. In the narrative style section was still poor, the accuracy of words and sentences were also poor, the accuracy of the development of the plot was sufficient, but for the suitability of the contents of the story and the accuracy of the selection of details, the story was good so the results obtained from this synopsis were of good value.

\section{4) Manis Jangan Mudah Ditelan}

In this story, twelve values of character education were found, namely hard work, honesty, discipline, religious, independent, curiosity, responsibility, friendship, respect, love for the motherland, brave, and never give up. From the results of the synopsis and assessment rubric the writer could be completed very well.

\section{B. Discussions}

In this part of the discussion, each title that has been developed into a synopsis form has several criteria assessed such as, conformity of story content, accuracy in selecting detailed stories, the accuracy of the flow development, accuracy of words and sentences, and writing style. From the predetermined criteria then adjusted to the results of student writing.

Based on the results, table 1, table 2, and table 3 are parts that have the same results so that the number of levels of student performance that can write a synopsis is also the same. The description of number 1 was very poor, number 2 was poor, number 3 was adequate, number 4 was good, number 5 was very good. 
TABLE 1. THE NUMBER OF STUDENTS WHO CAN MAKE A SYNOPSIS BASED ON THE CONFORMITY OF STORY CONTENT

\begin{tabular}{|c|c|c|c|c|c|}
\hline \multirow{2}{*}{ Rated Aspect } & \multicolumn{5}{|c|}{ Performance Level } \\
\cline { 2 - 6 } & $\mathbf{1}$ & $\mathbf{2}$ & $\mathbf{3}$ & $\mathbf{4}$ & $\mathbf{5}$ \\
\hline Conformity of story content & 2 & 2 & 2 & 4 & 4 \\
\hline
\end{tabular}

TABLE 2. THE NUMBER OF STUDENTS WHO CAN MAKE A SYNOPSIS BASED ON THE ACCURACY IN SELECTING DETAILED STORIES

\begin{tabular}{|l|l|l|l|l|l|}
\hline \multirow{2}{*}{ Rated Aspect } & \multicolumn{5}{|c|}{ Performance Level } \\
\cline { 2 - 6 } & $\mathbf{1}$ & $\mathbf{2}$ & $\mathbf{3}$ & $\mathbf{4}$ & $\mathbf{5}$ \\
\hline $\begin{array}{l}\text { Accuracy in Selecting } \\
\text { Detailed Stories }\end{array}$ & 2 & 2 & 2 & 4 & 4 \\
\hline
\end{tabular}

TABLE 3. THE NUMBER OF STUDENTS WHO CAN MAKE A SYNOPSIS BASED ON THE ACCURACY OF THE FLOW DEVELOPMENT

\begin{tabular}{|l|l|l|l|l|l|}
\hline \multirow{2}{*}{ Rated Aspect } & \multicolumn{5}{|c|}{ Performance Level } \\
\cline { 2 - 6 } & $\mathbf{1}$ & $\mathbf{2}$ & $\mathbf{3}$ & $\mathbf{4}$ & $\mathbf{5}$ \\
\hline $\begin{array}{l}\text { The Accuracy Of The Flow } \\
\text { Development }\end{array}$ & 2 & 2 & 2 & 4 & 4 \\
\hline
\end{tabular}

Furthermore, in table 4, the number of students has increased in understanding words and sentences. As many as 5 people have met the criteria well.

TABLE 4. THE NUMBER OF STUDENTS WHO CAN MAKE A SYNOPSIS BASED ON THE ACCURACY OF THE WORDS AND SENTENCES

\begin{tabular}{|l|c|c|c|c|c|}
\hline \multirow{2}{*}{ Rated Aspect } & \multicolumn{5}{|c|}{ Performance Level } \\
\cline { 2 - 6 } & $\mathbf{1}$ & $\mathbf{2}$ & $\mathbf{3}$ & $\mathbf{4}$ & $\mathbf{5}$ \\
\hline $\begin{array}{l}\text { The Accuracy Of The Words } \\
\text { and Sentences }\end{array}$ & - & 2 & 3 & 5 & 4 \\
\hline
\end{tabular}

Next, in table 5 which contains the narrative style, students are very good. even though the number of students is not too much, but it can represent the number of students who understand how to write or speak the results well.

TABLE 5. THE NUMBER OF STUDENTS WHO CAN MAKE A SYNOPSIS BASED ON THE WRITING STYLE

\begin{tabular}{|l|c|c|c|c|c|}
\hline \multirow{2}{*}{ Rated Aspect } & \multicolumn{5}{|c|}{ Performance Level } \\
\cline { 2 - 6 } & $\mathbf{1}$ & $\mathbf{2}$ & $\mathbf{3}$ & $\mathbf{4}$ & $\mathbf{5}$ \\
\hline The Writing Style & 2 & - & 3 & 4 & 5 \\
\hline
\end{tabular}

From the results of the study obtained data that, of the fourteen samples used only one student who scored very poor, one student got poor, one student achieved adequate, five students were categorized good, and six students were categorized very good. In other words, students were already good in terms of synopsis text reproduction, but on the other hand they still needed a lot of learning so that what was written on the original text did not disappear when it was rewritten.

TABLE 6. PERCENTAGE OF ASSESSMENT RESULTS MAKE SYNOPSIS

\begin{tabular}{|l|c|c|c|c|c|c|}
\hline N & Assessed & \multicolumn{5}{|c|}{ Performance Levels } \\
\cline { 3 - 7 } o. & Aspects & $\mathbf{1}$ & $\mathbf{2}$ & $\mathbf{3}$ & $\mathbf{4}$ & $\mathbf{5}$ \\
\hline 1 & Conformity & 7,14 & $7,14 \%$ & $7,14 \%$ & 35,71 & 42,85 \\
\hline
\end{tabular}

\begin{tabular}{|l|l|l|l|l|l|}
\hline & $\begin{array}{l}\text { of story } \\
\text { content }\end{array}$ & & & & \\
\hline 2 & $\begin{array}{l}\text { Accuracy in } \\
\text { selecting } \\
\text { detailed } \\
\text { stories }\end{array}$ & & & \\
\hline 3 & $\begin{array}{l}\text { The accuracy } \\
\text { of the flow } \\
\text { development }\end{array}$ \\
\hline 4 & $\begin{array}{l}\text { Accuracy of } \\
\text { words and } \\
\text { sentences }\end{array}$ & & & & \\
\hline 5 & Writing style & & & & \\
\hline
\end{tabular}

\section{CONCLUSION}

From the results of the discussion, it is very clear that folklore in South Sumatra cannot be separated from the value of character education. Although there is only one value of character education, the story element still leads to the value of good education. For example, in the story of Sang Miskin, Asal Usul Harimau Tidak Mau Memakan Orang Rambang, Asal Usul Talang Tampe Rawas, and Putri Berambut Putih, there are only values of responsibility and love of peace. After researchers reread and assess the results of the synopsis, it turns out that there is still a friendly or communicative value and social care gained from the story. This is because the synopsis writer is not right in choosing the details of the story and the development of the plot so that only some of the values of the Education character appear.

In a story that has a very good value, it means that the story writer has re-written the reading results in accordance with the contents of the story, the story details, plot, sentences, and the narrative is easy to understand. It can also be concluded that the better the process of reading the writer will produce better writing and in accordance with the original text. It cannot be denied when the writer will start writing, then what they need is a source of inspiration which in this case can be done by reading the original text in detail, so that no part is left behind and the rewritten results can be read correctly and clearly.

Besides that, it is related to the purpose of research, after students can rewrite in the form of synopsis, then the process of making teaching materials in Sanggar Sastra courses will be easier. Teaching materials such as handouts or even audiovisual materials are made from synopsis of folklore so that learning will be more interesting for students.

\section{REFERENCES}

Abidin, Y. (2016). Reading Learning Based on Character Education (Pembelajaran Membaca Berbasis Pendidikan Karakter). Bandung: Refika Aditama.

Beach, R. W., \& James, D. M. (1990). Teaching Literature in The Secondary School. Retrieved from https://eric.ed.gov/?id=ED363894

Creswell, J. W. (2007). Qualitative Inquiry \& Research Design: Choosing among Five Approach. London: Sage.

Denzin, N. K., \& Lincoln, Y. S. (2009). Handbook of Qualitative Research. Yogyakarta: Pustaka Pelajar.

Ghanbari, B., Barati, H., \& Moinzadeh, A. (2012). Problematizing Rating Scales in EFL Academic Writing Assessment: Voices from Iranian 
Context. English Language Teaching, 5(8), 76-89. https://doi.org/10.5539/elt.v5n8p76

Helaluddin. (2016). Application of Catalisting Strategies in Writing Processual Paragraph (Penerapan Strategi Catalisting dalam Menulis Paragraf Prosesual). Dialektika, 3(2), 216-228.

ol: A Case Study of Effective Practices and Processes. International Journal of Teacher Leadership, 8(2), 49-67.

Khrabrova, V. (2016). Graph Description as An Issue in L2 Academic English Writing. Journal of Language \& Education, 2(4), 46-54. https://doi.org/10.17323/2411-7390-2016-2-4-46-54

Kurnianto, E. A., Nirmala, V., \& Rosita, E. (2009). Folklore of South Sumatera (Kumpulan Cerita Rakyat Sumatera Selatan). Palembang: Language Center of South Sumatera.

Mulyati, Y. (2007). Indonesian Elementary Language Skills (Keterampilan Berbahasa Indonesia $S D$ ). Jakarta: Universitas Terbuka.

Nadya, N. L. (2018). Today's Literacy: Writing Short Stories with Heart. 10th Malaysia International Conference on Languages, Literatures \& Cultures, (1), 1-4. Melaka, Malaysia: Universitas Putra Malaysia.

Nadya, N. L., \& Amalia, F. N. (2019). Needs Analysis of Local Millenial Fairy Tales Textbooks. Proceedings of the 28th International Conference on Literature: Literature as a Source of Wisdom, 426433. https://doi.org/10.24815/.v1i1.14477

Nassaji, H. (2015). Qualitative and Descriptive Research: Data Type Versus Data Analysis. Language Teaching Research, 19(2), 129-132. https://doi.org/10.1177/1362168815572747 https://doi.org/http://dx.doi.org/10.15408/dialektika.v3i2.5185

Jakobs, E. (2003). Reproductive Writing-writing from Sources. Journal of Pragmatics, 35, 893-906.

Khoury, R. (2017). Character Education as a Bridge from Elementary to Middle

Scho

Nurgiantoro, B. (2011). Competency Based Language Learning Assesment (Penilaian Bahasa Berbasis Kompetensi). Yogyakarta: BPFE.

Omar, Y. Z. (2019). Teaching Pedagogical Grammar in Context to Enrich English Language Learners' Academic Writing. International Journal of Linguistics, Literature and Translation, 2(3), 213-225. https://doi.org/10.32996/ijllt.2019.2.3.24

R. Ghamrawi, N. A., Ghamrawi, N., \& Shal, T. (2015). Perception of Character Education: The Case of Lebanese School Leaders. Open Journal of Leadership, 04(04), 129-142. https://doi.org/10.4236/oj1.2015.44012

Saglam, H. I. (2011). An Investigation on Teaching Materials Used in Social Studies. Turkish Online Journal of Educational Technology, 10(1), $36-44$.

Tannir, A., \& Anies, A.-H. (2013). Effects of character education on the selfesteem of Intellectually able and less able elementary students in kuwait. International Journal of Special Education, 28(1), 47-59. https://doi.org/10.1016/j.promfg.2015.07.761

Tavares, R. R. (1990). The Connection between Reading and Writing: Theoretical Foundations and Some Techniques. Fragmentos: Revista de Língua e Literatura Estrangeiras, 3(2), 57-66. 